\title{
PAMPA BANDERA. MEDITACIONES SOBRE LA TIERRA Y EL TERRITORIO EN EL FILM CUATREROS DE ALBERTINA CARRI
}

\author{
Pampa Bandera. Meditations on land and territory on Albertina Carri's Cuatreros
}

\section{Adrián Esteban Cangi*}

\section{Resumen}

El artículo aborda el film Cuatreros (2016) de Albertina Carri desplegando arqueológica y genealógicamente las nociones de tierra y territorio, centrándose en la descripción poética de la mítica tierra y de la geografía material llamada "Pampa Bandera", por la que transitaron los perseguidos cuatreros Velázquez y Gauna. Se abordan las nociones conceptuales de tierra y territorio al mismo tiempo que se interroga la autoctonía y fundación, a través de la que se piensa la biografía fabulada y el mito político, anudados entre la tierra baldía y el territorio de la insurrección, mientras se cuestiona críticamente cualquier forma de taxonomía cartográfica.

$$
<\text { Tierra }><\text { Territorio }><\text { Frontera }><\text { Estética }><\text { Política }>
$$

\begin{abstract}
This article analyzes the film Cuatreros (2016), directed by Albertina Carri. In the first place, I will inquire on the notions of land and territory, resorting to archeological and genealogical perspectives, focusing on the poetic description of this mythical land, as well as on the material geography known as "Pampa Bandera" (the territory where the pursued cuatreros Velázquez and Gauna travelled). Secondly, I will address the concepts of land and territory and, at the same time, I will question the notions of autoctonía and fundación. These last concepts are important since they help us to conceive the fabled biography and the political myth, which are related to the wasteland and the insurrection territory. In addition, any form of cartographic taxonomy is critically contested.
\end{abstract}

$$
<\text { Land }><\text { Territory }><\text { Frontier }><\text { Aesthetics }><\text { Politics }>
$$

Recibido: 01/10/2017 // Aceptado: 10/12/2017

\footnotetext{
* Doctor en Filosofía y Letras / Pos-doctor en Filosofía y Letras. Profesor titular Regular de "Estéticas Contemporáneas". Universidad Nacional de Avellaneda. Departamento de Humanidades y Artes. Maestría en Estéticas Contemporáneas Latinoamericanas. adriancangi@hotmail.com
} 
Cangi. Pampa Bandera. Meditaciones sobre la tierra y el territorio en el film Cuatreros de Albertina Carri.

\section{Confines}

Desde las aventuras fotográficas de Guido Boggiani en la descripción y delimitación de tipos étnicos en el Gran Chaco del siglo XIX a la problematización contemporánea del territorio de la insurgencia de Isidro Velázquez que elabora Albertina Carri, tierra y territorio quedan entramados entre el mito y la historia. Es a través de la instalación Operación fracaso y el sonido recobrado. Investigación del cuatrerismo (2015) y del film Cuatreros (2016), que Carri insiste en dos registros directos testimoniales y una arqueología de imágenes de archivo. Las condiciones de producción que Albertina Carri utiliza entre la instalación y el film se concentran en el tratamiento de los vestigios de información sobre el pasado. Los datos, documentos y registros que conforman la recuperación de la memoria a partir de archivos encontrados -publicaciones, correspondencia epistolar, guiones y fragmentos fílmicos- son el sustento de una mirada que interroga una política de archivos. Por lo tanto se trata de una producción que trasciende lo biográfico y se inscribe como un autorretrato que, remitiendo a la lectura de una historia personal, familiar y de un país, interroga sin embargo la materialidad y los dispositivos que refieren a los discursos que atraviesan diversos medios y sus tecnologías para presentarse primero como una serie de instalaciones y luego como una forma de cine expandido. La combinatoria de documental y ficción, la variedad de soportes y formatos -fílmicos y electrónicos-, el uso de la animación y de la intervención tipográfica marcan una escritura que excede la cuestión propiamente cinematográfica para abrirse a los problemas del arte contemporáneo. El pasaje del cine al museo y del museo al cine reubica el documental reflexivo dentro del museo y lleva el museo a la sala cinematográfica, dando lugar a una doble exhibición museística y cinemática que ofrece una nueva lectura política sobre la historia reciente de la Argentina. La instalación presentada en la sala PAyS forma parte de un proyecto institucional que pone en la escena una memoria política en tanto interviene en el Parque de la Memoria tomando distancia de los lugares comunes de las artes audiovisuales, y, a la inversa, el film modifica la cultura del espectáculo y su relato dominante orgánico con su proyección en las salas de cine.

Entre los registros directos, una secuencia muestra a su hijo caminando sobre una línea punteada de la carretera y la otra presenta una imagen inhóspita de Pampa Bandera, región de la provincia de Chaco. La primera revela la fuerza del impacto de la ampliación de los derechos civiles a través del matrimonio igualitario; la segunda, presenta la mítica tierra que habitaron los cuatreros insurgentes Velázquez y Gauna que transitaron en su huída sobre el fondo de un territorio que lleva el nombre de un crimen: la masacre de Napalpí. La tierra de Pampa Bandera es donde la mirada no puede penetrar mientras que el territorio político de la desaparición de los cuerpos, tanto indígenas como cuatreros, puede ser interrogado en la ausencia de un mítico film, Los Velázquez, de Pablo Szir. Cuatreros avanza rodeando por capas de vestigios, huellas y restos un film ausente y una historia mítica, sin privarse de debates histórico-políticos. Pampa Bandera es simultáneamente una región y lo que se opone a la mirada: es tierra, territorio, frontera y confín. Atmósfera de una geografía alucinada y territorio de la 
resistencia de un pueblo. En el fluir del grano de la voz del acto de habla que articula las imágenes se siente la escritura densa que se vuelve síntoma entre el tambalear y la firmeza del decir:

El viaje a Pampa Bandera guardaba más sorpresas aun, aunque pensándolo bien con el niñito muerto ya me debería haber vuelto. La primera y más contundente revelación es que el lugar es un desierto espinoso, no un monte espinoso como leí en varias investigaciones. Son kilómetros y kilómetros de árboles enanos repletos de espinas del tamaño de agujas de tejer, tierra seca que se te mete en los ojos y no te deja ver, y cuando cede unos milímetros la nube de polvo en la que estás envuelta de sol a sol, se ven cadáveres de animales en diferentes estados de putrefacción. Es tal la sequía, el calor y la falta de recursos que la aridez se te mete en el alma hasta el desmayo. Realmente es mágico cómo dos hombres pudieron sobrevivir a la intemperie en una zona tan desgraciada. Las seis mil hectáreas que ahora nombran como "Comunidad Indígena" no tienen un solo servicio, son seis mil hectáreas cubiertas de espina y por debajo tierra cuarteada. El puntero de la zona te dice con orgullo que esas son las tierras que el gobierno otorgó finalmente a las comunidades originarias. Entre que te tengan en ese infierno, o te hagan ir caminando de los valles calchaquíes a Quilmes no hay mucha diferencia, como tampoco hay mucha diferencia entre vivir en esas tierras hoy o que te disparen desde aviones como le hicieron en ese mismo lugar a los indios en la masacre de Napalpi."Todo puede ser peor", me digo mientras arrastro a mi familia por esa geografía alucinada. "¿Y si hacemos que Velázquez y Gauna tengan una historia de amor? Digo, para que tenga alguna gracia la cosa, porque esto es de una aspereza...". En ese viaje la única película que puedo imaginar es una cámara estática, un plano secuencia de dos horas atravesado por la nube de polvo. Cada tanto, detrás del polvo, se percibe alguna presencia humana. Pero cada vez que estás a punto de ver una cara, de entender una forma como parte de un cuerpo, cada vez que te creés que alguien viene o se va, la nube lo borra todo y estás de nuevo en esa tiniebla blanca, clarita, que te hace creer que en algún momento vas a descubrir qué hay detrás. Pero no. El dominio de la nube se extiende más allá de lo imaginable, se vuelve a henchir de polvo en segundos y aquello que parecía real se disipa en el lagrimal. Sí, los ojos te lloran, todo el tiempo, solos. Los ojos se vuelven unos órganos incontrolables que duelen y no sirven para nada porque las 
lágrimas no te dejan ver. La tierra seca volando, metiéndose en los pulmones, en las hendijas más inhóspitas del cuerpo, es la autoridad suprema de esos confines.

Voz que rodea evocando la tierra y el pueblo desaparecido a través del diálogo con la palabra de sus padres: la del joven sociólogo Roberto Carri, autor del libro para la acción revolucionaria Isidro Velázquez. Formas prerrevolucionarias de la violencia (1968) y de la joven Ana María Caruso, profesora de literatura, cuyas cartas desde el cautiverio construyeron un modo de diálogo ético con sus hijas sin melancolía. En el intento infructuoso de acercarse al épico cuatrero y a la fuerza del mito que éste evoca, Carri lo hace a su vez con la trágica acepción de la insurrección popular, que inspirara un film y a un realizador igualmente desaparecidos tanto como la vida de los revolucionarios de su tiempo que se llevó a la de sus padres. La búsqueda de la instalación y luego del film es la de crear un montaje alucinatorio de vestigios que abordan en la actualidad una "revolución fallida", que la voz firme de la cineasta acepta y cuestiona. Acepta cuando se proyecta hacia la decisión de sus padres en un tiempo político de oligarquías y desigualdades feroces; cuestiona cuando mira el proyecto cubano con los rasgos del encierro y la miseria de una áspera dignidad frente al capitalismo mundial integrado. Por momentos la voz es irónica cuando problematiza los principios épicos de la revolución y por momentos se presenta plena de humor para abordar su propia maternidad rodeada de la muerte de cuerpos convertidos en proyectos de piltrafa.

Enfrentamos un verdadero film metonímico hecho de huellas y restos de cuerpos ausentes que se constituye como una sinecdoque de la idea de la Argentina, para articular una potente alegoría de la memoria como una fabulación plástica borroneada y desdibujada para cualquier intento de realismo con pretensiones de objetividad del relato y de sus relaciones retóricas entre lo visible y lo decible. Los cuerpos ausentes, el film desaparecido y la tierra de la muerte son los temas y materiales de un "documental subjetivo" (Arfuch, 2015) que no permite cerrar una relación entre vida y obra, pero que cuestiona por igual la catarsis y la solemnidad para conservar un punto de vista crítico, tanto sobre la pertenencia a unos nombres "nobles" de la historia política como a una distancia infranqueable respecto de una memoria del pasado.

La periodista de uno de los fragmentos de archivo pregunta: "Señor, estamos hablando de cambios, cambios de clima, de ambientes, cambios muy particulares. ¿Cuáles piensa usted que fueron los logros y cuáles las frustraciones?”. El entrevistado responde: “¿Logros? Le diría que uno, la paz". En ese archivo utilizado se ve al presidente de facto Galtieri, quien acaba de decir algo que la serie de imágenes que Carri articula cuestiona, entre el mugido de una vaca y su voz confesional. El ensayo fílmico se mueve entre la figura vaciada por las series que construye y el concepto que problematiza la representación de lo visible por el acto de habla, de cara a lo irrepresentable de la desaparición de los cuerpos, archivos y films. El carácter paradigmático, proyectivo, jerárquico y referencial de las imágenes como figuras de una semejanza con el mundo y consigo mismas es cuestionada por Carri al proponer una instalación y un film en los que el concepto que construye, a través de series, funciona por conexión, vecindad y 
consistencia sintagmática de las relaciones. Este desplazamiento de la figura al concepto es parte de su ensayo fílmico que vacía la representación para pensar la ausencia, aunque insiste en hacerlo dentro del lenguaje del cine. Pensar en este caso consiste en trazar un plano que absorba la tierra de Pampa Bandera, como territorio impenetrable de la génesis de la violencia revolucionaria, en la actualidad de la mirada y crianza de su hijo. Pensar no parece ser solo un hilo tensado entre sujeto y objeto presentes o ausentes para el relato que la voz trama, sino que se hace entre la tierra de Pampa Bandera y el territorio teológico-político de un proyecto articulado de la desaparición argentina. Tanto la instalación como el film elaboran una dialéctica en suspenso de la que emergen las series de sus figuras y conceptos.

Algo potente e inactual se abre en la nebulosa de polvo de Pampa Bandera: una tierra, un pueblo, una resistencia, una promesa para un tiempo venidero. Algo se levanta en esa tierra que no permite ver nada, allí se actúa contra el pasado vacante, y de este modo sobre el presente del efecto del acontecimiento de la desaparición que modificó nuestra historia; a favor, espero, de un tiempo venidero y de un porvenir que no sea ni utópico ni sustancializado, sino que permita la intensidad de la transformación del instante intempestivo. Lo actual, parece decirnos Carri, no es lo que somos sino más bien aquello que llegamos a ser cuando nos transformamos en otros. En el film no se confunde el devenir democrático con los estados de derecho, aunque los derechos ampliados permiten pensar el porvenir de su hijo frente a la desaparición de la historia. Carri no escribe sobre el pasado ni revisa archivos en nombre del presente, sino que inscribe una actualidad intensa entre el polvo de Pampa Bandera y el porvenir geográfico de una "revolución fallida", que continúa por otros medios en la experimentación del ensayo fílmico y vital, en la que su hijo prosigue la saga de los nombres de la historia y en la que Carri no cesa de preguntarse por las relaciones venideras entre tierra y territorio, entre biografía fabulada y mito político, entre autoctonía y fundación, entre tierra baldía y territorio de la resistencia insurreccional.

Albertina Carri se pregunta en el modo de producción entre la instalación y el film cómo abordar el mito de Velázquez y un modo insurreccional de la violencia de los sesenta. Reza la estrofa del chamamé El último Sapukay, de Oscar Valles: "Camino de Pampa Bandera/lo esperaban en una emboscada/y en una descarga certera/ruge en la noche la metrallada./Isidoro Velázquez ha muerto/enancao en un sapukay/pidiendole rescate al viento/que lo vino a delatar,/pidiendole rescate al viento/que lo vino a delatar." Del fondo de la tierra de Mburucuyá proviene el "santo pagano", como lo conocieron los miles de adeptos en Chaco, Corrientes, Misiones, Formosa y Paraguay, a quien hiciera del monte su refugio. Lapachito y Colonia Elisa cobijaron al llamado "rastreador" de esteros y montes, como la larga tradición poética de la gauchesca nacional lo hizo, al hostigado por las autoridades, al perseguido por la ley, al cuatrero que se volviera mito. Enfrentamientos policiales, secuestros de estancieros y hacendados, causas por robos y hurtos coronan su fama delictiva que reunió primero a los hermanos Velázquez hasta la muerte del menor el 21 de mayo de 1962, y a Isidro Velázquez y Vicente Gauna después, dupla perseguida por la sociedad rural chaqueña y la Policía Federal. Velázquez jugó su 
vida entre Machagay y Quitilipi, donde fue perseguido junto a Gauna por 800 policías, mientras se perdieron en una reserva toba que los protegió. En el gran camino de retorno entre ambos poblados, los encontró la noche del 1 de diciembre de 1967. La causa policial indica que 30 efectivos descargaron 500 balazos sobre el auto que los conducía, que acabaron primero con Gauna, y luego con Velazquez a 300 metros del auto contra un árbol mítico. La delación por la recompensa une a una maestra y a un cartero. Había muerto "el vengador", como los pobres vecinos de Pampa Bandera llamaron a Isidro Velázquez, aquel que ejerció una redistribución violenta de la riqueza. Ofrendas y amuletos, tributos y altares recuerdan hasta hoy al "último sapukay".

Las formas de la violencia se gestaron entre el crimen y la miseria extrema, entre el mito y la memoria de la opresión argentina. En el prólogo del libro de Roberto Carri, con el que inicia el parlamento de Albertina Carri en el film Cuatreros, se enuncia:

Más importante que la crónica de los sucesos es la significación actual de los mismos. Este estudio de la rebeldía popular debería conectarse con el estudio de las formas políticas que la expresan. Toda política tiene una ideología, Velázquez es una forma política de la rebeldía y el sentimiento popular es en cierto modo la ideología

Los varios registros documentales simultáneos con multiplicidad de pantallas en la pantalla cinematográfica, con los que trabaja Carri, suponen diversos registros de distintas procedencias, con texturas visuales de los sesenta y setenta que rodean el centro vacío del mito de Velázquez, para hacer aparecer los restos de su figura por los efectos de formaciones decibles y visibles. Albertina Carri toma la voz del texto de su padre, prosiguiendo por otros medios aquella interpretación política en nuestro tiempo. La voz de la hija dice con las palabras del padre:

Con esto, siguiendo a Fanon, quiero decir que la certeza es adecuación a los hechos, pero la verdad para el pueblo es aquello que perjudica al enemigo... Y Velázquez, hoy, es ya parte de la cultura de nuestro pueblo, el sentimiento que despertó su acción, su práctica concreta, son patrimonio de los oprimidos en áreas rurales del Chaco.

El film Cuatreros, en el 2016, vuelve sobre los pasos del libro Formas prerrevolucionarias de la violencia de 1968 de Roberto Carri, que supo bucear en el mito popular de la emboscada en la que muere Isidro Velázquez en 1967. El núcleo de la recursividad de la memoria histórica en este "documental reflexivo" (Nichols, 1997), enuncia que lo reprimido y lo desaparecido retornan como restos de un inconsciente óptico y de una fabulación oral, más allá de la desaparición de cuerpos y materiales. Retornan por la fuerza de una huella y por la de una fabulación popular sobre aquellas capas de la memoria pasada, que sin embargo son problemáticamente actuales. La memoria no existe de manera simple sino múltiple, como reordenamiento de huellas 
según renovadas concernencias. Las imágenes del recuerdo no son reflejos invariables de la vivencia, son un producto complejo de la superposición de capas de la memoria registradas como huellas vividas en diferentes variedades de signos. Cuatreros hace de esta lógica de la memoria un modo de organización narrativa cristalina que presenta distintas capas simultáneas en la continuidad de preguntas sobre la argumentación narrativa. Del mismo modo utiliza los materiales de archivo como soportes visibles y decibles para volver sobre el pasado y sus huellas como una nueva concernencia. Ausencia y leyenda se traman entre sí en Cuatreros para rodear a la tierra de Pampa Bandera. La voz del padre proletarizado, "chupado" según la jerga en 1977, habla por la rabia, por momentos cercanos y por momentos distante, de la voz de la hija, que organizando un torrente verbal articula, como en una novela de aventuras proliferante sobre un centro vacío, la polifonía de voces de la historia. Como nos ha hecho sentir Godard en Historia(s) del cine (1988), la voz de la historia está hecha de voces de múltiples historias y las imágenes están hechas de capas arqueológicas y genealógicas de otras imágenes. En este film comparece la voz del padre, de la madre, de la hermana. Las voces de Lita Stantic, de Fernando Peña, de Mariano Llinás. Y la voz siempre mítica de Pablo Szir. La complejidad de imágenes de archivo y de ficción dialoga sobre la reconstrucción de un mítico film desaparecido y sobre la posibilidad de contar un relato sobre la figura mítica de Velázquez, siempre huidiza para ser alcanzada en su complejidad por un relato orgánico

Estas voces rodean el núcleo de un debate argentino y de sus restos sobre un fondo vacío de la tierra y sus figuras, bajo la conquista de ese espacio mítico por el territorio teológico-político del estado de excepción. La propaganda de archivo antisubversiva citada en Cuatreros se pregunta por el territorio orgánico, teológico y político del Estado represivo argentino: “¿Quién? ¿Por qué? ¿Dónde? ¿Cuándo?” mientras reúne la serie de estas preguntas en una imagen de la palabra "Control". Control contra los organismos extraños, foráneos, anómalos, cuatreros, por el que bregaron las voces de Rojas, Aramburu, Videla, Massera, Galtieri, para reunir en un mismo territorio teológicopolítico del estado de excepción una lucha interna biológico-lingüística con el objetivo de eliminar lo reprimido popular por la práctica de un plan sistemático cívico-militar de desaparición forzada. La tierra de Pampa Bandera es el espacio impenetrable del mito sobre el que gira el film Cuatreros, al mismo tiempo que constituye el nombre imposible de los huecos que deja la narración sobre esta geografía incierta que cobija los fracasos paradójicos de la historia argentina deseada. Fracasos de una dialéctica imposible y forma de un hiato ejemplar. Albertina Carri sabe mostrar que solo en el hiato o en el intervalo es posible una dialéctica en suspenso que rodea, más allá del sujeto y del objeto tratado por la narración, el centro vacío de la tierra donde el mito de Velázquez desató la violencia del oprimido y constituyó la santidad de la creencia popular; donde el mito inició la emoción popular que no se deja atrapar por una forma de narración ni épica ni trágica, para retornar con la fuerza de una pregunta sobre la tierra inabordable y sobre el territorio codificado. 
Cangi. Pampa Bandera. Meditaciones sobre la tierra y el territorio en el film Cuatreros de Albertina Carri.

\section{Arqueología}

Carri nos invita a una arqueología de la memoria para deslindar tierra y territorio, nociones que hunden sus efectos en la tradición occidental y se proyectan sobre el plano conceptual que absorbe la tierra de Pampa Bandera. Martin Heidegger en Construir Habitar Pensar (1951) y Gilles Deleuze y Félix Guatari en El Antiedipo (1985) le otorgaron precisión a las nociones de tierra y territorio. Ambas nociones se distinguen en la intersección de su contacto. Tierra es la unidad primitiva que expresa la extensión indivisible, mientras que territorio es el objeto múltiple del logos y del nomos, del discurso y de la ley en el espacio-tiempo político, dividido por el trabajo humano. Tierra y suelo se distinguen y superponen. Se dirá sin embargo que Tierra es el elemento superior a la producción política del valor, mientras que suelo es producción y apropiación como territorio de la potencia social transformada en trabajo colectivo que engendra valor, definiendo el límite y la interioridad de un espacio. Pero es también Heidegger, críticamente leído por Adorno, quien en Por qué permanecemos en la provincia (1934), retorna a la Tierra pensada como lugar sacrificial donde se vierte la sangre, como el lugar de lo originario y la autoctonía utilizada para justificar la superioridad de etnias o lenguas en la jerga de una autenticiddad que pretende autofundarse.

En "Geofilosofía", capítulo central de ¿Qué es la filosofía? (1991) de Gilles Deleuze y Felix Guattari, se afirma: "Pensar se hace más bien en la relación entre el territorio y la tierra". De este modo los autores atribuyen un desplazamiento del pensamiento del par sujeto/objeto hacia el par tierra/territorio, estableciendo que la filosofía moderna y contemporánea construiría una "geografía de la razón" (Kant) que se abre a los problemas de una "intuición originaria" (Husserl) y de una relación entre "ser y ente" (Heidegger). Deleuze y Guattari afirman que no puede decirse cuál de estos términos va primero, si tierra o territorio. Por ello se preguntan en qué sentido es posible pensar tanto la potencia en la tierra de la filosofía como el spatium de la ciudad-Estado en el territorio del filósofo, aunque ambos términos formen entre sí un medio inseparable. De esta forma, pensar consiste en trazar un plano que absorba la tierra en el territorio. La filosofía sería así una "geofilosofía" de modo equivalente a cómo la historia se presentaría como una "geohistoria". Es lo que sostienen Fernand Braudel en Civilización material, economía y capitalismo (1979) o Marcel Detienne en “¿Qué es un sitio?” (1990), para indagar en las relaciones entre autóctono, fundación y desterritorialización.

En la delimitación entre Tierra y territorio aparece siempre el límite y el espacio del habitar. El habitar se representa para los saberes arqueológicos, arquitectónicos y filosóficos como un acontecimiento cósmico y existencial en un tiempo histórico, en un ciclo repetitivo que conserva el orden del mundo. Presupuesto religioso que está en la base de su constitución espacial: el axis mundi representa la conexión entre Tierra y territorio, entre Tierra y cielo, como la columna universal que asegura la continuidad entre cosmos y mortales. Desde la centralidad del eje, todo el trabajo del edificar se subordina a un símbolo ritual, aquel del vallum, o división del espacio en cuatro partes 
referidas al centro. La fabricación de un mundo está ligada al mito de la Fundación, que desde Roma se proyecta a los territorios conocidos. Símbolo que delimita una totalidad espacial y la religa con una unidad cósmica, individualizando el espacio como un lugar protegido. A través de la raíz hundida en el omphalos de la Tierra, la urbs se convierte en mundus, para sostener en el propio territorio de Roma y en todo territorio conquistado la insistencia de los rituales de Fundación y Autoctonía. La morada no es desde luego un objeto, es el universo en el que el hombre se construye emulando la creación ejemplar de la cosmogonía.

El límite y el espacio interiorizado que conforman la ciudad como lugar del habitar, es un oikos a través del cual se busca y se encuentra una determinación de la vida, una práctica política y una oikonomia (una práctica del cuidado económico del habitar) para la vida en común. En ese espacio coinciden precariedad y técnica como forma de relación entre vida y espacio, entre fluidez y tiempo. En ese acto de constitución está en juego algo oscuro, algo sustraído a la conciencia y que además se ha configurado como radical exigencia de sacralización de la existencia. A ese algo se lo llama Tierra e insiste en el territorio para satisfacer la necesidad de una protección material y temporal como expresión simbólica de una protección cósmica. La unidad entre los artefactos y su imagen simbólica viene realizada por el acto técnico de construir. Este acto debe percibirse como un gesto de naturaleza religiosa, y por él y en él se juega la existencia humana. Historiadores y arqueólogos, antropólogos y geógrafos, coinciden que en el subsuelo de Occidente hay una compleja mitología que rodea a la noción de Tierra. Noción escurridiza y opaca que se pierde en genealogías, estratos y transformaciones entre tradiciones míticas y teológicas, literarias y filosóficas, poéticas y conceptuales. Se dice que la Tierra ha sido forzada a volverse "madre" ante la mirada violenta de una ciudad territorial "masculina". Los lugares del habitar han balizado la tierra a fuerza de ley y discurso, como huellas espacio-temporales del mismo existir "por" y "en" la casaciudad, como ámbitos políticos y territoriales que no pueden abordarse sin batallas.

En Totalidad e infinito (1961), en el apartado "La morada" (Lévinas, 2012: 169-192), el filósofo Emmanuel Lévinas enuncia que la razón de la casa resume a la de la ciudad, pues ésta no es sino una proyección. Sostiene que en la casa encontramos simultáneamente lo finito económico-utilitario y lo infinito trascendente del ser. Bajo la fórmula "morar es errar", el filósofo recupera la raíz judaica del libro e intenta desmontar de la casa-ciudad tanto el trauma griego de la falsa Autoctonía como el trauma bíblico de la Culpa, ambos entramados en todas las Fundaciones de Occidente. La casa representa el lado "de acá" de la vida (goce y utilidad) y por lo tanto la condición de posibilidad del trabajo y de la posesión. Pero también contiene el lado "de allá" de la relación del hombre con la Naturaleza y con lo otro (goce y trascendencia). Cuerpo y conciencia se reúnen en la morada en su proyección a la ciudad. De este modo, Lévinas sostendrá que "la casa no enraíza al ser en una Tierra para ponerlo en comunicación vegetal con los elementos (...) ella mantiene los bienes al sol, pero también su secreto”.

Esta desmitificación de la casa-ciudad es sinónimo de la deconstrucción del fundamento ontológico de la vida en la Tierra, y en el suelo transformado en paisaje y 
Cangi. Pampa Bandera. Meditaciones sobre la tierra y el territorio en el film Cuatreros de Albertina Carri.

territorio. Lévinas escribe "la casa elegida es todo lo contrario a una raíz. Indica más bien un desapego, una errancia que la torna posible, que no es minus en el instalarse, sino un plus de la relación con otros". La casa, y su proyección a la ciudad, no enraízan al viviente a la Tierra, porque en ella la errancia continúa bajo la forma de la libertad. O bien cerrarse sobre sí o bien abrirse a los otros, son condiciones de posibilidad de la casa-ciudad. Es tan esencial, sostiene Lévinas, el abrirse como el cerrarse, tanto al goce utilitario como a la trascendencia solitaria. ¿En qué radica el secreto que encontramos en este planteo? Radica en enfrentar una doble genealogía que se superpone en la tradición occidental. Por un lado aquella griega por vías de Eurípides; y por el otro, aquella cristiana por vías del Génesis. A pesar de esta citación no olvidamos sin embargo la crítica que León Rozitchner realiza en sus libros Lévinas o la filosofía de la consolación (2013), Cuestiones cristianas (2013) y Génesis. La plenitud de la materialidad histórica (2015), a la noción de tiempo congelado, libertad absoluta y crimen absoluto, para pensar la relación entre el "no matarás" patriarcal y el ocultamiento del "vivirás" materno, dentro del campo de una filosofía de la historia. Húmeda y negra, opaca y profunda, Tierra es el agujero mayor donde se muere. "Y nosotros hemos salido de una Tierra... así que de todas formas teníamos que retornar allí". Seca y volando, árida y cuarteada, Tierra es la autoridad suprema de los confines. "Y nosotros hemos salido de una Tierra... así que de todas formas teníamos que retornar alli". Las fabulaciones de occidente han girado sobre la fertilidad de la tierra húmeda o sobre la tierra árida de los confines. Así Cuatreros retorna para la construcción del mito a esta misma insistencia sobre Pampa Bandera y a la figura que de allí emergió: Isidro Velázquez.

\section{II}

El territorio es en principio una delimitación política arbitraria legitimada por un orden simbólico, que se impone desde alguna institución. La representación cartográfica como potencia de proyección y de conquista que impone territorios es el efecto político de una verdad que tranquiliza, la de la representación única y homogénea que en su omnipotencia cree conocer, cuando lo que hace es matar analizando, o construir taxonomías objetivas cuando clasifica en un ejercicio de vida/muerte, al dejar dentro/ fuera lo que selecciona como legítimo o ilegítimo. El problema es que esa superficie reprime, contiene, censura la explosión de una variedad de pulsiones. Mapas rasgados o cronologías subvertidas dan cuenta de ese destello instantáneo en el que Historia, verdad y sujeto se manifiestan como máscaras que quieren fijarse para no soportar el devenir en permanente fluctuación. En esta línea se puede hacer la genealogía de ese mapa canónico naturalizado que da cuenta de los territorios, los cuerpos, los sexos, las lenguas, las palabras, las pasiones y acciones toleradas en el marco de visibilidad. Pero podemos descomponer el mapa en los elementos mitológicos que oculta. Si no hay génesis de naturaleza noble, si no se trata del mapa como copia de la realidad ni como unidad global del mundo civilizado ligado a la más alta racionalidad, entonces es el resultado de un juego de fuerzas: operación espuria que debe ser velada bajo la forma de un germen prístino. 
La forma anodina del mapa y sus delimitaciones fronterizas oculta, en los territorios que impone, las formas de vaciamiento, en la que "desierto" es la palabra principal con la cual se describe lo que se suprimirá más tarde. El desierto es como un límite del que pende toda imagen de la ciudad, entendida en su ser más concreto y físico, pero emplazada en las lindes del desierto. Las fabulaciones argentinas siempre nos colocan de cara a ese mítico desierto concebido como tierra baldía; una "cosa" que, como la arena, no es lejana sino próxima, interna incluso a los habitantes que van de la ciudad a los espacios vacantes. En una página poética, escribe Edmond Jabés en Del desierto al libro (1980) que "lejos de expulsarnos, el desierto nos envuelve. Nos tornamos arena, como escribiendo somos el libro". Es Hannah Arendt sin embargo quien plantea, en Los orígenes del totalitarismo (1951), que las matanzas administrativas consisten en determinar espacios vacíos como hicieron los ingleses al cartografiar África -o Fernando de Lerma al fundar Salta en nuestra versión local- , para luego vaciarlos en lo real. Lo trágico consiste en que todo lo que es representable puede ser abolido en un segundo momento. Genocidios que se olvidan porque no fueron nunca representados en ningún presente. Es el jurista nacionalsocialista Carl Schmitt, rehabilitando las categorías políticas centrales de amigo/enemigo en Tierra y Mar. Una reflexión sobre la historia universal (1942), quien plantea que la historia universal es la historia de la lucha de las potencias marítimas contra las terrestres y de las terrestres contra las marítimas. Comprensión cabal de una cartografía del poder, donde las fronteras no son nunca naturales sino como producto de una lucha de fuerzas que le antecede. También las fronteras pueden ser pensadas como permeables, mutantes, lugares de tránsito de identidades diaspóricas (Gloria Anzaldúa, 2007) o semiósferas, donde subjetividades en permanente negociación semiótica dan cuenta de su carácter de siempre "recienvenidos" en el habitar cotidiano, según la expresión de Macedonio Fernández (Camblong, 2004), o incluso desde topologías que piensan la reversibilidad de nociones como interior/ exterior y adentro/afuera. La idea de nación es un relato que se funda en un mito que permite hacer de la Tierra, el territorio. Y esa fabulación oscila entre la Autoctonía y la Fundación que permiten diferenciar al extranjero del originario.

Eurípides se pregunta por el arraigo del primer nacido en sus obras Erecteo e Ion. El autóctono, consagrado a la Tierra, es capaz de constituirse a sí mismo y de resistir a las fuerzas externas. El nombre de Erecteo cruza la consustanciación con los dioses y las huellas políticas de la casa-ciudad, en una coexistencia simultánea de disputas en torno al dolor de la fundación. Autoctonía y Fundación se superponen en las huellas de una herida, y entre una y otra existe una suerte de antipatía, y esto se prolonga hasta la época contemporánea, en los medios que piensan la raigambre propia del territorio, como en las moradas de aquellos intérpretes e historiadores, hoy etnólogos y geógrafos. Esta antipatía está ligada al espacio y al límite que establece un odio viejo y rancio hacia el inmigrante -aquel bárbaro o extranjero- que se confunde una y otra vez con el llamado autóctono. ¿No habrá venido el autóctono de otra parte?, se pregunta el antropólogo e historiador de las religiones Marcel Detienne en Dioniso a cielo abierto (1986) y en Cómo ser autóctono (2003). Las maneras de marcar territorio son múltiples y no cesan de mezclarse al ser inventadas. Los inventores de estas marcas políticas las hacen 
Cangi. Pampa Bandera. Meditaciones sobre la tierra y el territorio en el film Cuatreros de Albertina Carri.

“jugar" para generar el "sitio", pero luego se las recuerda para "juzgar", y con ellas se afianzan las instituciones de una sociedad. Podemos también pensar a Erecteo, en la línea de Eurípides pero desde una perspectiva descolonial, como el autóctono "macho", padre y rey fundador de satélites de la gran metrópoli. Y a Medea, bruja conocedora de los saberes de los arcanos, como aquella a quien nunca le será perdonada su condición de extranjería, y que por ello se vuelve ajena incluso a la relación con sus propios hijos.

El suelo de la casa-ciudad como territorio, será consagrado a santuarios transformados luego en marcas políticas, que tiemblan por las sacudidas de una profunda grieta que proviene del subsuelo de la Tierra. Erectéo, el Autóctono, es inseparable de Praxítea, la sacerdotisa política, que levanta los cimientos de la ciudad para mostrar el lazo secreto entre religión y política, para revelar quién es la Autóctona y Fundadora, aunque luego haya sido desplazada por el poder de la sangre y el linaje masculinos. La antropología de los mitos y la historia de las religiones muestran una y otra vez que el primer nacido, como lo sabe Herodoto, siempre se encuentra cercano a la raíz y a la tumba, al olivo y a las oraciones fúnebres. Por ello la casa-ciudad se funda sobre la patria del primer nacido, como un territorio más preciso que la Tierra, aunque siempre codificado por los rituales de la lengua y del cuerpo, donde nacen las justificaciones que le otorgan al primer nacido voz y voto, y lo ungen para los rituales de sangre y de defensa por las armas, para volverlo al fin la estirpe nobiliaria y la residencia natural del suelo.

Las obras Timeo y Critias de Platón retoman estos problemas y los disuelven en todas las mitologías de las Repúblicas y Naciones modernas que articulan la relación entre Autoctonía y Fundación, cruzando de este modo ontología y política, al fijar el germen mítico de aquello que define el interior de un territorio político de aquello otro considerado opaco o indiscernible bajo el nombre de Tierra. Finalmente las fronteras, esos bordes de lo político que definen a los que son o no parte del "todo" territorializado, son delimitaciones de ese topos político, no ya del territorio sino de la eclessía -asamblea de los iguales- que la habita, y lugar del ethos donde se acuña la resistencia de los cuerpos y donde la Tierra cobija a la humanidad, como señaló Heidegger en Construir Habitar Pensar. El espacio creado, según Heidegger no es sólo un spatium intermedio sino una extensio numérica, una extensión algebraico-matemática que permite desvelar la conversión de la Tierra en territorio por las técnicas de producción. Esto distingue el espacio creado por lugares de la memoria religiosa-política, de aquellas otras como puras extensiones para la producción en el territorio. Lugar y espacio matemático se distinguen para Heidegger de la noción de Tierra, por ser esta última extensa, opaca y trascendental, mientras el lugar y la extensión, son espacios creados por su límite, donde conviven y se superponen lo sagrado y lo profano. Del Heidegger leído por Carlos Astrada en la filosofía argentina de Tierra y figura (1963), emerge la insistencia de una pregunta que proviene de la tragedia y que busca su localidad entre nosotros: cuál es la figura de una Tierra mítica que pueda decir lo común. Este es el problema sobre el que el film Cuatreros se articula, dando lugar a vincular Pampa Bandera como lo opaco indiscernible que cobija la figura épica de Velázquez. Figura que para la memoria 
popular es el abrigo trascendental de un misterio que ocupa en nuestro medio el lugar narrativo del mítico Erecteo. Isidro Velázquez se confunde con el mito del "vengador" en nombre de la autoctonía del primer nacido, del mismo modo que vuelve a la Tierra como el "santo pagano" en que se constituyó.

\section{III}

Los relatos mítico/religiosos que atraviesan la historia dando lugar a concepciones antropológicas o a problemas propios de la geografía y de la sociología moderna, son los núcleos de la formación política de Occidente, que constituye a Oriente como límite o aún más como concepto del límite. Desde las tragedias griegas hasta los epitafios nacionales modernos, la casa-ciudad guarda sus difuntos en la tierra mientras siente odio por los extranjeros. Todos los muertos en defensa del territorio son confiados al suelo definido en su límite por la casa-ciudad y a la Tierra como abrigo trascendental en su misterio. Los cementerios nacionales son para la arquitectura el abrigo de la "madre Patria" y sus posibles genealogías y linajes, para que el caído en batalla retorne del lugar de soldado anónimo al sitio donde fue nutrido. Autoctonía y Tumba son figuras conectadas por oraciones fúnebres y epitafios que dan lugar a las grandes elegías modernas nacionales, y en su reverso viven los mitos partisanos y las figuras de una historia insurrecta.

El mito del primer nacido es el "alma" de las narraciones de la nación moderna, porque vinculan nacimiento y muerte en defensa del espacio definido políticamente en sus límites. La figura de Erecteo, como el primer griego autóctono, dio lugar a las narraciones nacionales europeas y amerindias durante los siglos XVIII y XIX. En nuestro medio esta figura es reemplazada por el Autóctono de los grandes linajes indígenas, aquel que mantiene viva una relación entre el mundo animal y la humanidad en confrontación a las incertidumbres del cultivo y de la cultura en el suelo. Lo que media entre Tierra y territorio es la "cosa" política, que permite el pasaje del "territorio sagrado" al "territorio político". Al primer nacido se lo llama gegénito, el bautizado autóctono que se presenta en todas las tradiciones como una figura estéticamente híbrida: mitad serpiente de ondulantes pliegues y mitad viejo con máscara de rey. De la Cecropea griega a la serpiente emplumada de mil máscaras del Popol Vuh, se repite la progresión de una figura de mezclas o de una figura de umbral. Las fabulaciones sobre esta figura de umbral están abordadas por Lezama Lima en La expresión americana (1957) como procesos de una cosmogonía dudosa e inventiva. Lezama Lima advierte que las dificultades expresivas del Popol Vuh se atribuyen a las criaturas que surgen en las nuevas regiones, aunque a él lo hacen pensar en adecuaciones, interpolaciones y paralelismos hechos por copistas aguerridos, jesuitas irritados y graciosos filólogos españoles del siglo XVIII, para sembrar complejos terribles en lo americano de paralelismos universales.

Habrá que recordar también que Gaia, la Tierra para los modernos, Pachamama en las cosmovisiones amerindias, entra en escena por las transmutaciones de sus materiales y figuras. Cuando se piensa políticamente el territorio en todas las tradiciones 
occidentales, siempre encontramos una profundidad mistérica y una superficie a labrar. Vida y muerte, sacrificio y fertilidad, reúnen instrumentos de labranza con órganos humanos, producción entre lo profano y lo divino con especies cultivables. Marcar la tierra es el primer gesto mítico del ethos político que hombre y mujer asumen y soportan para formar parte del territorio. La casa-ciudad es un lugar paradójico, porque se hunde y se construye simultáneamente, entre exilio y redención, entre fuga y salvación, mitológicas que se encuentran en el origen de la política para ocultar los asesinatos primordiales en que se fundan. El territorio se justifica en una política de la autoctonía y en la fundación de una genealogía mítica. Como sugiere Fernand Braudel en el libro que recoge la construcción de las mitologías nacionales modernas, llamado La identidad de Francia (1986), si hay una explicación sobre el territorio nacional debe salir del laboratorio de la identidad y de las experiencias, de las continuidades y de las reglas tendenciales, de las repeticiones y de la historia profunda de una sociología retrospectiva. Una nación no puede ser más que a expensas de buscarse a sí misma constantemente en la política del territorio, de transformarse en el sentido de su propia evolución lógica, de oponerse a otros sin desmayo, de identificarse con aquello que las mitologías consideran lo mejor y lo más esencial de sí. Los parlamentos de Braudel recogen todas las historias modernas nacionales sobre el territorio y resuenan en obras fundamentales de nuestra tradición, como Restos pampeanos. Ciencia, ensayo y política en la cultura argentina del siglo XX (1999), de Horacio González. Todo el problema narrativo de los archivos utilizados por el film Cuatreros se centra en mostrar la política sobre el territorio teológico-político para definir la pretendida identidad argentina discutida entre los proyectos nacionales y la desaparición cívico-militar.

\section{Genealogía}

La cronología clásica de la historia de la filosofía moderna comienza con el cógito cartesiano que instaura al sujeto de la representación en el centro del campo escópico, y del cual el cinematógrafo es el invento de las técnicas del siglo XIX que se proyectan en los imaginarios del sueño o del recuerdo del siglo XX. Este es el pasaje a la época de la imagen del mundo, según Heidegger. $\mathrm{O}$ al mundo como imagen representada que lo vuelve asequible y dominable. Con el peligro consecuente de que todo lo que adquiere estatuto de representabilidad, puede ser abolido con las mismas estrategias con que se lo visibilizó. De ahí el nacimiento de la cartografía, ligada al surgimiento de los imperios coloniales, como necesidad de graficar, mensurar, imaginar y proyectar los espacios a subordinar, conquistar, vaciar o llenar. En todos los casos, representar es siempre dominar y conquistar a partir de una primera visualización imaginaria y proyectiva que pone en juego una tensa ficción entre la constitución del mapa y la superficie terrestre aún no convertida en territorio -como lo hace Borges en el relato "Del rigor en la ciencia" (1946) -. La cartografía deviene así un dispositivo para territorializar que se despliega desde los variados relatos de viajeros, desde el siglo XVI hasta el XIX inclusive, que se desplazan entre la ciencia y la literatura. Se van 
conformando así los estados nacionales, amparados en estas cartografías imaginarias cuyo reverso y complemento son las narraciones de las épicas de dominio territorial y las justificaciones que los discursos del saber y el poder les otorgan (Anderson, 1993). Cualquier pregunta por la nación moderna va acompañada de restos de cartografías y de relatos, como lo muestran tanto el geógrafo Sergio Cimbaro en Una nueva visión de la cartografía (2014) como el sociólogo Horacio González en Restos pampeanos (1999).

Abandonando el matiz sustancialista de la noción de territorio frecuentemente unida al estado nacional, que establece fronteras y con ellas la integridad de un espacio, queda abierta la operación del aparato moderno destinado a la producción de artificios de uso colonial y poscolonial, donde se puede pensar la frontera como una "semiósfera" compleja de prácticas y signos de diversidad que se resisten a ser colonizados por la lengua y la cultura simbólica dominante, como lo muestra Ana Camblong en Habitar las fronteras... (2004). Se trata de cuestionar el habitus (Bourdieu, 1997) que nos mantiene en las retóricas del saber y del poder en nombre de conocimientos técnicos o conmemorativos, o de aquellos otros ligados a la seguridad territorial a través de los mapeos y calendarios surgidos del ojo vigilante materializado por cámaras y registros de identidad virtual. Territorio es un espacio cartográfico balizado física y simbólicamente por técnicas proyectivas de dominio, que obliteran cartografías sensibles propias de la riqueza de una semiósfera, a partir de una delimitación política arbitraria legitimada por un orden simbólico impuesto desde alguna institución. Un espacio único en un tiempo homogéneo se liga a la estética como disciplina de una ciencia imposible: la filosofía. Pero la cartografía posee ese estatus epistemológico en la medida en que es la construcción de un espacio delineado por los imperios coloniales, que conjuntamente desplegaron una filosofía burguesa de la historia organizando una temporalidad unilineal y progresiva: una crono y topo política (Bajtin, 1990).

La cartografía a partir del geógrafo Mercator, que establece el planisferio convencional en 1569, es un invento europeo útil para la navegación ultramarina, articulado desde un ojo panóptico que establece rutas de navegación, dimensiones productivas, separaciones políticas, delimitaciones administrativas, y si bien respeta formas, cae en la desmesura de los tamaños. Vale preguntarse si se trata de errores de una proyección matemática o modos de visibilidad de un ojo eurocentrado. Estas fronteras, que provienen de una larga tradición que hunde sus fabulaciones en el mito, señalan el límite entre lo humano y lo animal, lo normal y lo anómalo, lo civilizado y lo salvaje, desfigurando lo que no entra en los territorios que fundan, luego de vaciarlos de sus propias matrices sensibles. El mapa es el resultado de una imposición hegemónica que no obedece a una mímesis de lo existente, sino a una versión imaginaria de lo que se está dispuesto a ver, después de haber eliminado cualquier forma de vida previa como en Pampa Bandera con la masacre de los indios de Napalpí. Retrospectivamente, esto ya era evidente en la descripción que Colón hizo en su Diario del Primer Viaje a las Indias (1492), no solo de la Isla a la que nunca vio como continente, sino de los nativos a quienes describió semióticamente como si fueran parte de una naturaleza a descifrar. 
Aquello que queda como no representable, como resto, es el conjunto de fuerzas antagónicas de sentido inverso que no se acomodan a las fronteras establecidas ni a los espacios habitados e inhabitados ya convertidos en topografías. En su versión moderna, el mapa busca legitimarse en la cientificidad de sus proyecciones, desconociendo la arbitrariedad de sus puntos de partida. Pero primero es preciso cuestionar la modernidad como un marco histórico imaginario y proyectivo de un régimen de signos que necesita la representación del espacio a partir de un ojo que establece las coordenadas del campo escópico, sustrayéndose de él. Ojo cartesiano que mira sin ser mirado y que objetiva deícticamente, como lo han sostenido por igual Martin Jay en Regímenes escópicos de la modernidad (1988), Susan Buck-Morss en Dialéctica de la Mirada (1989) y Eduardo Gruner en El sitio de la mirada (2002), en sus analíticas de los regímenes de construcción perceptivo del espacio moderno.

El campo de la mirada, como el del lenguaje, organiza espacio y tiempo en función de su estructura deíctica, su aquí y su ahora. Solo basta con preguntarnos por las condiciones de enunciación del mapa para darnos cuenta de la mirada organizadora que lo configuró. Es su ausencia constituyente la que permite la naturalización de un modo de representación como ocurre con Pampa Bandera. Esa enorme fábula en la que consiste la ciencia moderna, fundada en mitologías griegas y cristianas, a las que se suma la idea de progreso, es la que sanciona la proyección Mercator que, plagada de convencionalismos, logra sin embargo que convención y realidad se identifiquen perceptivamente. Para sostener tamaña frontera, fue necesario poner a Dios como regulador canónico, como el gran Cartógrafo, cuyo ojo consagra la distribución de mares y de tierras, legitimando la mirada del Rey, que luego se transformará en la mirada del Estado teológico-político destinado a eliminar todo aquello que ponga en juego su proyecto territorial de racionalización, stock y control del paisaje. Un pasaje del trabajo de archivo de Cuatreros revisa la publicidad dominante durante la dictadura cívicomilitar en la que se concibe la represión del organismo anómalo que debe ser eliminado por el control del territorio. Por lo tanto, se sacraliza un modo de representación que implica que su disolución o incluso cuestionamiento conllevará siempre improntas ateas o al menos heréticas. La retórica cartográfica implica sobre todo simultaneidad, yuxtaposición y coetaneidad. No trabaja con el eje diacrónico sino sincrónico, lo que produce un efecto de sentido totalizador. Y como toda retórica no solo persuade sino que arma figuras paradigmáticas y jerárquicas que ponen en relación lo conocido y lo desconocido de acuerdo a los cánones no explicitados del sujeto de la enunciación.

\section{II}

La delimitación territorial será un instrumento de saber y poder, y un problema de seguridad cuando se demarquen los estados nacionales. El uso político militar de la frontera, visible en las cartografías oficiales es realizado en la Argentina por el Instituto Geográfico Militar, recientemente renombrado como Nacional, lo cual implica un cambio en la concepción: las fronteras no son cuestiones inherentes a las fuerzas armadas, sino al conjunto de la nación. Se trata entonces de cuestionarse si el mito del 
Ejército ha sido reemplazado por el mito de la Nación. Junto a la construcción territorial, se produce la delimitación de espacios de pertenencia, de naturaleza o cultura, de etnias y de lenguas, de patrimonios locales o de la humanidad. La pregunta que surge es si las teologías políticas que constituyeron un mundo organizado jerárquicamente fueron luego secularizadas para mantenerse siempre canónicas. Esas posiciones expresan una lucha de fuerzas sublimada en diversas hermenéuticas. Momento de la producción de una mirada y una representación: necesaria cuando los colonos fuera de las grandes metrópolis deben conservar el centro frente a la proliferación fáctica de las diferencias periféricas. Las perspectivas comunes debilitadas por la distancia conducen a que la única manera de sostener tanto la unidad de la corona y la identidad del imperio como las lógicas del Estado sea la de fundarse en un conjunto de escrituras sagradas y de figuras ritualizadas por cartografías diversas, que no pueden darse el lujo de ser fluctuantes o de establecer sus propias condiciones de enunciación.

Así, el mapa asume una función primordial: fijación ante la posibilidad de dispersión o resistencia frente a la amenaza de pérdida de la identidad. Este sentido restringido y en apariencia neutro es el que oculta más eficazmente el elemento teológico-político que se articula en la representación imaginaria de lo real. El orden público de la cartografía y su difusión mediante las instituciones adquiere ese carácter normativo, pero fundamentalmente cerrado y diferenciado de otras miradas que serían apócrifas o falsas, no consideradas u olvidadas, y sin valor de ley, por ejemplo el mapa trazado por el cronista Guamán Poma del territorio y prácticas de vida durante la colonización del Virreinato del Perú, en su Primer nueva crónica y buen gobierno (1615). Junto con la elaboración de la cartografía se van tramando los inventarios de plantas y animales, de razas y etnias, de reservas humanas y de parques nacionales, todo lo cual desembocará en la invención de la naturaleza moderna, tal como lo vio Alexander von Humboldt en su Viaje a las regiones equinocciales del Nuevo Continente (1804). Esos gestos de delineamientos fronterizos, de construcción de taxonomías y de clasificaciones evolucionistas tuvieron un claro carácter de imposición, que se respaldó en la idea de cientificidad y que leyó en la superficie de seres bióticos y abióticos su condición de objeto y su valor de cambio. Desde esta normativa se viró a la noción de autenticidad, y aún de pureza, sin mestizaje, que se atribuyó a los orígenes impolutos de una historicidad fabulada, que siempre ocultará el nombre de las comunidades indígenas que habitaron la tierra como en Pampa Bandera.

Entre los siglos XIX y XX la cartografía prosiguió en sus tácticas de demarcación planetaria, pero recibió una fuerte crítica que comenzó con los procesos de la comprensión del paisaje bajo la "historia natural" y que prosigue aún hoy en los análisis y prácticas descoloniales. El proceso de institucionalización, primero de los imperios y luego de los estados nacionales, creció con el del establecimiento de un canon. Y la crítica del canon se transforma en rebelión contra la autoridad, "parricidio textual", como dice Nicolás Rosa en Los fulgores del simulacro (1987). Por eso, una revolución implica un cambio de calendario y otras formas topográficas, revolución que siempre, luego de corromper un sentido, estabilizan otro. Las taxonomías y cartografía como instrumentos de poder 
Cangi. Pampa Bandera. Meditaciones sobre la tierra y el territorio en el film Cuatreros de Albertina Carri.

en las sociedades crecientemente secularizadas del siglo XVII y XVIII, van a legitimar el estatuto de los territorios y luego de las razas, los cuerpos y los sexos, basados primero en la legitimación teológica y elevados luego a disciplina científica, a partir de un saber crecientemente secularizado que establecerá quién es cosa, animal o persona; autóctono o extranjero; bárbaro y alienígena. Extrañamente, ese orden representacional solo guía a quienes conquistan territorios pero no a los llamados "naturales" que no encuentran siquiera modo de leerlos, como bien lo describe el antropólogo Viveiros de Castro en Los involuntarios de la patria (2016).

Los Estados (cosmopolitas o nacionales) no pueden forjarse sino a partir de una pedagogía que eduque tanto al pueblo para que forme parte de esa humanidad letrada, como a los pueblos específicos cuyo saber de sí se conceptualiza en el estado nacional. Las disciplinas como saberes, pero también como formas de disciplinamiento se organizan para establecer las relaciones de poder y saber entre la elite intelectual y la masa (siempre anárquica, femenina, infantil, voluble) que es fuente de cambio tanto como instancia de conservación de lo propiamente nacional. Surge entonces la necesidad de establecer conjuntamente una geografía, una literatura, una historia y una lengua comunes como formas de delimitación de una identidad que será narrada en los museos y defendida por el ejército del estado nacional moderno. De ahí que el servicio militar obligatorio hará de cada ciudadano un soldado anónimo que habla el idioma oficial, que conoce las fronteras e internaliza los valores básicos de la nacionalidad, y que defiende con su cuerpo el territorio delimitado de la nación. Territorializar implica censurar lo que está fuera de la frontera, zona peligrosa donde se mezclan los distintos: lo natural y lo salvaje, las etnias y las razas, los dialectos y las lenguas, lo urbano y lo rural, los anómalos y los cuatreros.

En el texto de Franz Fanon Piel negra, máscaras blancas (1952), podemos pensar en los usos resistenciales de las operaciones cartográficas: las nociones de "territorializar" y "desterritorializar", como estrategias de un movimiento político que afectó a pensadores contemporáneos en sus análisis del capitalismo, como Gilles Deleuze y Felix Guattari en Mil mesetas. Capitalismo y esquizofrenia (1972). Una categoría puede ser utilizada para discriminar y, en un sentido opuesto, como factor de identificación para los sujetos políticos de una posible transformación. El potencial de muerte que en la enunciación se articula, es lo que permite comprender los sedimentos que anidan en esa expresión, consolidados en tratados de antropología, etnología, geografía y sociología; de criminología, anatomía forense, ciencias naturales e historia; de psicología, mitología, narratología, e incluso en las analíticas de los cuentos populares. El problema es leer en la expresión concentrada lo que, coagulado en sentido, obedece a un sinsentido "originario", lo que como pura fuerza ordenó lo real y luego se naturalizó por la vía de una descripción invisibilizada en tanto conjunto de argumentos y de trazos codificados. Los archivos abordados de manera insistente en la búsqueda de Cuatreros dan cuenta de este doble movimiento: ordenar lo real e invisibilizar a los cuerpos. El epicentro de este movimiento gira en el film sobre Velázquez y Gauna como mitos de unas fuerzas anómalas encarnadas entre la tierra y el territorio. 


\section{III}

Plantear una fuerza que rompe el mapa desde los márgenes territoriales, o que al menos los historiza desnaturalizándolos, supone demostrar el carácter totalitario que caracteriza a toda taxonomía, en la medida en que pretende ponerle un freno a lo real en materia de delimitación de espacios de recorrido, de patrimonios universales, de ámbitos inexplorados, o de cualquier otra forma manipulable para una racionalidad que corresponde a la voz del amo. Vale recordar la discusión y el conflicto irresoluble entre saberes evocados en la extracción y exhibición como objetos de estudio y exposición de las momias de Llullaillaco, entre las prácticas ceremoniales en la Tierra sagrada y el territorio profano del patrimonio de la ciencia nacional e internacional moderna. Vale preguntarse por la existencia de Tierras sagradas de los ancestros, aun no reconocidos en su expropiación, y que se resisten a la demarcación jurídica y económica de los estados nacionales en nuestra contemporaneidad. Pero no hay modo de romper las representaciones, sin vaciar la causa de lo divino, es decir el sentido "originario" que nos alertaría de que en la pasión supuestamente originaria del miedo, ya hay un tratado de teratología funcionando. Un dios puesto en el lugar del sentido solo puede transformarse en el jefe de una policía que somete a todo ente al lecho de Procusto: establece una medida, en la que debemos entrar de modo necesario, a costa de recortar lo que sobra o estirar para lo que no alcanza.

La Tierra como noción se conserva inengendrada, salvaje y opaca a su desvelamiento último, como los nobles cuerpos centauros de los cuatreros que la habitan, mientras que el suelo es segmentado por unidades matemático-algebraicas, para ser sometido a la extracción sin fin y a su conversión en stock. La Tierra es la inscripción primitiva del deseo de producción o "el motor inmóvil” sobre el que se desarrolla el suelo productivo como territorio de la máquina social. La unidad inmanente de la Tierra como motor inmóvil e inscripción primitiva del deseo de producción, da lugar al concepto de una unidad plástica y trascendental de una naturaleza por completo distinta al desvelamiento técnico del suelo como territorio político de la máquina social, de la seguridad nacional y de la producción y expropiación para el stock. Tierra y territorio se interceptan como un concepto plástico. Concepto que simultáneamente expresa su dimensión trascendental y empírica. Creemos que no puede pensarse el desvelamiento técnico del suelo como territorio político de la máquina estatal sin la unidad inmanente como inscripción primitiva del deseo de producción. Tierra es una justicia inmanente perteneciente a un orden no cronológico cuyas figuras míticas son para el territorio Autoctonía y Fundación. En la Tierra morimos y expiamos nuestro nacimiento, aunque su nombre permita esquivar todo aquello que se desarrolla en el territorio: ley y contratos, paternidades y maternidades, codificaciones y discursividades. Tierra es para la historia de las religiones y para la antropología de los mitos el tiempo primordial de los Autóctonos y el grado cero de la Fundación; y para la historia política, el germen de las formas prerrevolucionarias en las que los hombres pudieron sobrevivir a la intemperie de la tierra baldía en una zona desgraciada practicando la resistencia de una revuelta. 
Los lenguajes de las artes, como lo ha hecho el cine en su centro, siempre han visto el territorio como un paisaje intervenido o localizado por desacuerdos jurídicosociales o por proyecciones políticas. La geografía media entre la noción de Tierra y el espacio ecológico en el cual hombres y mujeres tejen sus dramas históricos. Hay que recordar a Carlos Astrada en Tierra y figura (1963) y Metafísica de la pampa (2007), como aquel que impulsa el pensamiento argentino y latinoamericano sobre la noción de "númen del paisaje" y de "historia natural", recuperando la tradición de Husserl a Heidegger pasando por Adorno, para pensar las relaciones entre Tierra, territorio, tradición y modernidad. "Historia natural" o "naturaleza Histórica" han permitido modular las relaciones entre Tierra y figura, entre hábitos y expresiones sociales, en los que la singularidad del sujeto se cruza con la racionalidad instrumental técnica. Los conceptos de "paisaje" y de "territorio" guardan en común el sentido de delimitación de la naturaleza. El primero se entiende como recorte de un espacio natural observado desde un lugar determinado, es decir como la representación de un paisaje que implica siempre una mirada construida a partir de un punto de vista que puede incluir otros a la vez. El territorio por su parte define una frontera teológico-política con modulaciones jurídicas sobre una extensión de suelo habitado o por habitar. Sus límites son una geografía política que se distingue respecto de otras. No basta declararlo, fundarlo o alambrarlo para que exista, tiene que ser reconocido en la representación como tal para quienes están dentro y fuera de sus confines. Cada demarcación supone un umbral entre "identidad" y "diferencia", entre "interioridad" y "excedencia", como parte de una presentación-representación en el que los lenguajes de las artes han sido implicados. Carri logra indagar con Cuatreros la tensión entre el "númen" de la tierra y el espacio territorial de la revuelta, devolviendo al cine su doble reflexión: sobre los límites de la representación de los archivos y sobre la voz testimonial del acto de habla que se eleva sobre la tierra para reclamar una fe en este mundo.

\section{Tierra y restos}

Narrativamente Cuatreros traza una aventura novelesca para alcanzar el secreto imposible del mito entre tierra y territorio, entre tierra y figura, donde conviven burla y parodia, apertura y suspenso, rodeo y evasión; donde se fondean archivos y se recuperan testimonios, aunque siempre se busque en todo material y en toda voz la espera insistente del rastro de los padres, de una época y de una cultura desaparecidos que imaginó otra tierra en el territorio político. El propio cuerpo ausente de sus padres se corresponde con el corpus del film desaparecido de Szir. Entre un libro y un film, por igual objetos de desaparición, es necesario desarmar cualquier distanciamiento con una representación fílmica que nunca se pretende un documento etnográfico porque no se sostiene sobre el saber de un sujeto sobre un objeto, y porque cualquier nexo indicativo en el film entre lo visible y lo decible está excedido por la desaparición de cuerpos y materiales. La autenticidad histórica está dada por los archivos y los testimonios en juego, pero pensada como una nueva potencia de ficción de la memoria. Este realismo experimental reflexivo y subjetivo elude cualquier pretendida "objetividad" porque la desaparición 
pone en exceso la distancia con una época, que sin embargo el film aborda de un modo ético para buscar los nombres y la evocación política de aquel tiempo en el nuestro. Inapelable resulta Carri cuando discute el estatuto de la representación narrativa del cine experimentando la desaparición en el propio material fílmico para trabajar sobre una construcción visible y decible por capas arqueológicas y niveles genealógicos que rodean la tierra de Pampa Bandera y la figura de Isidro Velázquez, evocando y asociando los problemas tratados conceptualmente por las grandes narraciones míticas de occidente. De este modo, cualquier representación reflexiva provoca preguntas sobre la constelación que gira entre la tierra que insiste opaca y la ausencia de los nombres de la historia traídos a la presencia por la figura del mito.

Los lenguajes de las artes contemporáneos están bajo sospecha pivotando sobre una pregunta que impregna al continente y al indócil Cono sur: “¿Qué lugar tiene un arte del cuerpo en un país de cuerpos desaparecidos?". Pregunta que estalla en esquirlas hacia direcciones diversas, para volverse anacrónica e intempestiva al presente, aunque deje huellas actuales en las calles y plazas argentinas. Pregunta que proviene del artista visual peruano Emilio Santiesteban, que resuena en otras preguntas equivalentes de nuestra América como la del colombiano Juan Manuel Echavarría: "y de los desaparecidos ¿quién habla?" (Diéguez, 2014), y que interroga a todas las prácticas orilleras que se posicionan a contramano de cualquier sentido concertado y de cualquier fantasía de los mercados globales plenos de un flácido esteticismo generalizado. Pregunta que corta la atmósfera en el exacto momento intolerable en el que la comunidad hace uso de ese engendro llamado "opinión pública", gestado en los fondos políticos del siglo XVIII $\mathrm{y}$ amalgamado con la educación sentimental y del gusto del pretendido ciudadano ilustrado, que se proyecta hoy como la escena de sentido común y de buen sentido moral de nuestro teatro del juicio, donde los actos públicos vuelven a los hechos fabulaciones posibles y a las imágenes presencias indoloras del horror a través de la repetición, la sobreexposición, la enumeración detallada, y otros precisos procedimientos retóricos y enunciativos, destinados a cauterizar el dolor intolerable que la pregunta abre en nosotros en el silencio de su insistencia: “¿Qué lugar tiene un arte del cuerpo en un país de cuerpos desaparecidos?".

Planteada esta pregunta, la misma se ubica en el centro del problema que nos conduce a otra, no menos precisa: ante la desaparición, ¿cómo es posible construir una imagen que remita a una ausencia, que le quite sustancia al mundo no para representarlo sino para indicar su condición? El imaginario viralizado en los medios de comunicación disuelve el horror por la preminencia de sus mecanismos técnicos de reproducción. Pero habría que dar cuenta de lo irreproducible, de la singularidad absoluta de la herida. Entre un lenguaje de las artes que pretende reparar por la representación el lazo social herido y otro que se retira en la sublime caída de la representación imposible para evocar la presentación vacía del dolor, insisten tensiones conceptuales que tocan de distintos modos el nervio poético de nuestro tiempo sobre un fondo trágico. Cuatreros combina restos de descripción con restos de representación, evidencia documental con problemas de ausencia de articulación lógica para la percepción. Sin embargo la descripción narrativa 
Cangi. Pampa Bandera. Meditaciones sobre la tierra y el territorio en el film Cuatreros de Albertina Carri.

de la voz sustituye con una pregunta la desaparición de los nexos indicativos y sensoriomotores de una lógica narrativa orgánica dominante: cómo un sujeto experimental histórico se enfrenta a un "objeto" inencontrable y a unos cuerpos desaparecidos, para plantearse un desplazamiento que interroga qué es un territorio teológico-político de la violencia y qué es una tierra constituyente pero inaccesible del mito. Este realismo poético de naturaleza simultánea, virtual y cristalina de las imágenes (Deleuze, 2005) opera con restos que pertenecen a la más antigua tradición literaria argentina, la que va de Sarmiento a Martínez Estrada, y de éste a David Viñas, y llega hasta las preguntas de Horacio González en Restos pampeanos. Este realismo puede leerse en las páginas del Facundo de Sarmiento "¿Qué impresiones ha de dejar en el habitante de la República Argentina el simple acto de clavar los ojos en el horizonte y ver... no ver nada?" (Sarmiento, 1999). Esta es la pregunta que prosigue Cuatreros cuando hunde los ojos en Pampa Bandera, en aquel horizonte incierto de la tierra del mito, tan vaporoso como indefinido, donde se confunde la visión, donde se fascina la mirada, donde se sume el cuerpo en la contemplación y la duda. Ese es el secreto de la tierra o de la vida de los elementos donde se desarrollará la figura del mito de Isidro Velázquez. Entre Sarmiento y Astrada, insiste la misma pregunta por la tierra, aunque abordada de modos diversos, que se junta con la creación de una figura y que reúne en un solo gesto mito y poética, númen del paisaje e historia popular. Albertina Carri recupera el fluido nervioso que subleva las pasiones y encienden los entusiasmos desde la tierra de Pampa Bandera, porque algo inexorable atraviesa la imaginación del pueblo en aquel medio imposible de fuerza natural del que emergió una figura que expresa una atmósfera social. La tierra no es un territorio teológico-político porque opera como un centro trascendental vacío que supone antes una emoción que una descripción geográfica.

¿Qué misterio guarda el rastreador Velázquez que lo une a tantos otros nombres de nuestra tradición para la memoria popular? Se dirá que el rastreador es un burlador de la ley y que su poder de distribución en la pobreza es un exceso de la fatalidad apremiante en la que se juega el sentido de la ventura social y el reparto igualitario de los bienes. Quien se atreve a estas fuerzas debe enfrentar sus vértigos y sus despojos. "Pampa Bandera" es un doble nombre enigmático: indica el vértigo de la mirada inhabitable y la localización de una tierra en el territorio balizado de la patria. Entre ambas huellas se dirá que este nombre es solo tierra invivible por el hombre pero habitada por el mito. El mito es el lugar de unas huellas de la memoria de la emancipación popular y de la reparación siempre pendiente de aquellos condenados de la tierra en los márgenes de la historia. Chaqueños, correntinos, misioneros, formoseños y paraguayos levantan altares al cuatrero en una cultura que no reconoce derechos de la propiedad del Estado sobre sus mitos populares ni sobre las pasiones de una tierra indómita que concentra una memoria de la opresión. Cuatreros es un documental reflexivo y subjetivo sobre deseos psíquicos colectivos y sobre íconos míticos que abre zonas inconscientes entre el tiempo del relato y de la historia. Nos enfrenta a un deseo indeleble y oscuro, atrapando un momento perpetuo en la figura de Isidro Velázquez, que no es otro para Albertina Carri que el de la desaparición de sus padres. El mito es un modo integral de experimentar lo narrativo trágico y lo referencial histórico que individualiza y sublima en la figura de Velázquez 
el sacrificio de los cuerpos en una tierra que constituye el númen de un paisaje que conserva su secreto. Los recuerdos populares sobre Velázquez son los recuerdos míticos de la nación. Su sacrificio sangriento ha sido un modo trascendental de la tierra y su figura que vuelve sobre el ritual de la pasión política que enfrenta a la opresión. Las acciones irracionales de Velázquez son tan punibles como los modos de opresión sobre los cuerpos que lo han elegido como ideal pasional y a Pampa Bandera como tierra del mito, oponiéndolos a cualquier intento instrumental de la territorialización cartográfica de la patria. Cuatreros se articula sobre la fuerza vacante e irrepresentable del espacio de Pampa Bandera como el negativo del territorio, como el fotograma lírico borroso, como la fuerza de la narración mítica y como el núcleo de la pregunta de la desaparición sin fin de las huellas de la memoria.

\section{Referencias bibliográficas}

AAVV. (2016). "Paisaje y territorio" En: Congreso de Tucumán: 200 años de arte argentino. Diálogos entre obras de la colección del Museo Nacional de Bellas Artes y de artistas contemporáneos, Buenos Aires, Ministerio de Cultura de la Nación.

Adorno, T. (2004). "El paisaje como tema de cultura". En: Teoría estética, Madrid, Akal. Adorno, T. (1992). "La idea de la historia natural". En: Actualidad de la filosofía, Barcelona, Paidós Ibérica.

Albán Achinte, A. (2008). "Sazones, Olores, Colores, Sabores y Saberes de la gastronomía afrocolombiana negra y raizal". En: AAVV, Catedra De Estudios Afrocolombianos : Aportes Para Maestros, Popayán, Universidad del Cauca.

Albán Achinte, A. (2005). Sabor, poder y saber. Comida y tiempo en los valles afroandinos del Patía y Chota-Mira. Colombia, Universidad del Cauca.

Anderson, B. (1993). Comunidades imaginadas, Mexico, Fondo de Cultura económica. Anderson, P. (1987). Transiciones de la antigüedad al feudalismo, México, Siglo XXI. Anzaldua, G. (2007). Borderlands. La Frontera. The new mestiza, San Francisco, Ann Lute Books. Arendt, H. (2006). Los orígenes del totalitarismo, Madrid, Alianza.

Arfuch, L. (2015). “Albertina, o el tiempo recobrado". En: http://www.informeescaleno. com.ar/index.php?s=articulos\&id=389

Astrada, C. (2007). Tierra y figura y otros escritos, Buenos Aires, Las Cuarenta.

Astrada, C. (2007). Metafísica de la pampa, Buenos Aires, Biblioteca Nacional.

Bajtin, M. (1990). Estética de la Creación Verbal, Madrid, Siglo XXI.

Benjamin, W. (2008). Sobre el concepto de historia, Madrid, Abada.

Benjamin, W. (2009). Estética y Política, Buenos Aires, Las cuarenta.

Bourdieu P. (1997). Razones prácticas. Sobre la teoría de la acción, Barcelona, Anagrama.

Braudel, F. (2009). La identidad de Francia, Barcelona, Gedisa.

Braudel, F. (1984). Civilización material, economía y capitalismo, Madrid, Alianza.

Brown, P. (1993). "Cuerpo y ciudad", "Andar sobre la tierra, tocar la alta bóveda del cielo" y "Los padres del desierto". En: El cuerpo y la sociedad, Barcelona, Muchnik.

Buck-Morss, S. (1996). Dialéctica de la Mirada, Madrid, Antonio Machado. 
Bueno, G. (1989). “Teoría general de la ciudad”. En: Ábaco, No. 6, La ciudad y el futuro de la metrópolis, Primavera, pp. 37-48.

Cacciari, M. (2010). La ciudad, Barcelona, Gustavo Gili.

Camblong, A. (2014). Habitar las fronteras..., Posadas, EDUNAM.

Charbit, Y. (2002). "The Platonic City: History and Utopia”. En: Population (English edition), $\mathrm{n}^{\circ} 2$, pp. 207-235.

Cimbaro, S. (2014). "Una nueva visión de la cartografía”. En: Cartografías del Poder y Descolonialidad, Buenos Aires, Ediciones del Signo.

Colón, C. (2012). "Diario del Primer Viaje a las Indias". En: Añón, Valeria y Teglia, Vanina (editoras), Diario, cartas y relaciones. Antología esencial, Buenos Aires, Corregidor.

Crampton, J. (2009). "The Political History of Cartography Deconstructed: Harley, Gall, and Peters". En: Mapping: A Critical Introduction to Cartography and GIS, Wiley-Blackwell, Oxford, UK.

Cuervo, O. 2017. "Sombras terribles”. En: http://tallerlaotra.blogspot.com.ar/2017/02/ sombras-terribles.html

Deleuze, G. (2005). La imagen-tiempo, Buenos Aires, Paidós.

Deleuze, G. y Guattari, F. (1994). Mil mesetas. Capitalismo y esquizofrenia, Valencia, Pre-textos

Deleuze, G. y Guattari, F. (1995). El Antiedipo, Barcelona, Paidós.

Deleuze, G. y Guattari, F. (1993). “Geofilosofia”. En: ¿Qué es la filosofia?, Barcelona, Anagrama.

Detienne, M. (2009). Dioniso a cielo abierto, Barcelona, Gedisa.

Detienne, M. (2005). Cómo ser autóctono, México, FCE.

Detienne, M. (1990). “Qu'est-ce qu'un site?”. En: Detienne, Marcel (ed.), Tracés de fondation, París, Peeters.

Diéguez, I. (2014). Cuerpos sin duelo. Iconografías y teatralidades del dolor, Nuevo León, Universidad Autónoma de Nuevo León.

Dillon, M. (2015). Catálogo de la muestra "Albertina Carri/Operación Fracaso y el Sonido Recobrado”. En: https://issuu.com/parquedelamemoria/docs/catalogo albertinacarri final simpl

Fanon, F. (2009). Piel negra, máscaras blancas, Madrid, Akal.

Giordano, M. (2012). "Las múltiples facetas de Guido Boggiani”. En: AAVV. Boggiani y el Gran Chaco. Una aventura del siglo XIX, Buenos Aires, Museo de Arte Hispanoamericano Isaac Fernández Blanco.

Godard, J. (2007). Historias(s) del cine, Buenos Aires, Caja Negra. Prólogo de Adriàn Cangi. González, H. (1999). Restos pampeanos. Ciencia, ensayo y política en la cultura argentina del siglo XX, Buenos Aires, Colihue.

Gruner, E. (2011). El sitio de la mirada, Buenos Aires, Norma.

Guamán Poma de Ayala, F. 2013. Primer nueva crónica y buen gobierno, México, Siglo XXI. Guerra, A. (2012). "El determinismo geográfico y la geografía árabe medieval. AlAndalusi e Ibn Jaldún”. En: Geoenseñanza, Vol. 17, (1) enero - junio, pp. 1-21.

Ginzburg, C. (2001). "El país”. En: El queso y los gusanos, Madrid, Península.

Golder, G. y Yeregui, M. (2016). Es la casa el territorio, Buenos Aires, UNTREF.

Hardt, M. y Negri, A. (2005). Imperio, Barcelona, Paidós.

Heidegger, M. (2015). Construir Habitar Pensar, Madrid, Oficina de Arte y Ediciones. 
Heidegger, M. (1980). "Paisaje creador. Por qué permanecemos en la provincia". En: Huerta, Marcos, La técnica y el estado moderno. Heidegger y el problema de la historia, Santiago de Chile, Universidad del Chile, pp. 60-63.

Hogan, R. (2009). Marx on the City: A Focused Archeology of Knowledge, Indiana, Purdue University.

Jacobs, J. (1975). La economía de las ciudades, Barcelona, Península.

Jay, M. (2003). "Regímenes escópicos de la modernidad”. En: Campos de fuerza. Entre la historia intelectual y la crítica cultural, Barcelona, Paidós, p. 221. Traducción castellana de Alcira Bixio de Force Fields.

Ibn Jaldún. (1977). Introducción a la Historia Universal, México, FCE.

Koza, R. (2017). “Los fragmentos”. En: http://www.conlosojosabiertos.com/cuatreros/ Leibniz, G. (2005). Protogaea, Oviedo, KRK.

Lévinas, E. (2012). Totalidad e infinito, Salamanca, Sígueme.

Lewis, M. (2014). La ciudad en la historia, Logroño, Pepitas de calabaza.

Lezama Lima, J. (2012). La expresión americana, Almería, Confluencias.

Michaux, H. (1983). Ecuador, Barcelona, Tusquets.

Moreno, M. (2015). "A las patadas". En: https://www.pagina12.com.ar/diario/ suplementos/radar/9-10992-2015-10-18.html.

Nichols, B. (1997). La representación de la realidad. Cuestiones y conceptos sobre el documental, Barcelona, Paidós

Paoli, U. (1981). Urbs, Barcelona, Iberia.

Peller, M. (2015). “Reseña de la instalación: Operación fracaso y el sonido recobrado de Albertina. Carri, Parque de la Memoria (Sala PAyS), CABA, 2015”. En: Aletheia, Vol. 6, No12, abril 2016. ISSN 1853-3701. (Disponible: http://www.aletheia. fahce.unlp.edu.ar/numeros/numero-12/practicas-artistico-culturales/resena-dela-instalacion-201 coperacion-fracaso-y-el-sonido-recobrado201d-de-albertinacarri-parque-de-la-memoria-sala-pays-caba-2015)

Rosa, N. (1987). Los fulgores del simulacro, Santa Fe, Universidad Nacional del Litoral. Rozitchner, L. (2014). Lévinas o la filosofía de la consolación, Buenos Aires, Conabip. Rozitchner, L. (2013). Cuestiones cristianas, Buenos Aires, Conabip.

Rozitchner, L. (2015). Génesis. La plenitud de la materialidad histórica, Buenos Aires, Conabip. Sarmiento, D. (1999). Facundo, civilización y barbarie, Buenos Aires, Emecé Editores. Schmitt, C. (2007). Tierra y Mar. Una reflexión sobre la historia universal, Madrid, Trotta. Schmitt, C. (2015). Stato, grande spazio, nomos, Milano, Adelphi.

Sennett, R. (1994). Carne y piedra. El cuerpo y la ciudad en la civilización occidental, Madrid, Alianza. Serres, M. (1995). Atlas, Madrid, Cátedra.

Serres, M. (1993). Filosofia mestiça, Rio de Janeiro, Nova Fronteira.

Sloterdijk, P. (2003-2006). Esferas I-II-III, Madrid, Siruela.

Suárez Ardura, M. (2006). "Paradojas de la Geografía". En: El Catoblepas, № 53.

Trías, E. (1976). El artista y la ciudad, Barcelona, Anagrama.

Trías, E. (1991). "Estética del límite”. En: Lógica del límite, Barcelona, Destino.

Varzi, A. (2001). "Philosophical Issues in Geography-An Introduction". En: Topoi 20:2, pp. 119- 130 . 
Vernant, J-P. (2001). La muerte en los ojos. Figuras del Otro en la antigua Grecia, Barcelona, Gedisa.

Veyne, P. (1991). "Naturaleza y uso de la mitología". En: La elegía erótica romana, México, FCE.

Virilio, P. (1999). La inseguridad del territorio, Buenos Aires, La marca.

Viveiros de Castro, E. (2016). Los involuntarios de la patria, Sao Paulo, Ediciones n-1. Wittgenstein, L. (2007). Tractatus Logico-Philosophicus, Madrid, Tecnos.

Von Humboldt, A. y Bonpland, A. (1984). Viaje a las regiones equinocciales del Nuevo Continente, Caracas. Monte Ávila.

Zarone, G. (1993). Metafísica de la ciudad. Encanto utópico y desencanto metropolitano, Murcia, Pre-textos/Universidad de Murcia. 